\title{
Effects of Streptomyces Biofertilizer to Soil Fertility and Rhizosphere's Functional Biodiversity of Agricultural Plants
}

\author{
Tinatin Doolotkeldieva, Saykal Bobusheva, Maxabat Konurbaeva \\ Plant Protection Department, Faculty of Agriculture, Kyrgyz-Turkish Manas University, Bishkek, Kyrgyzstan \\ Email: tdoolotkeldieva@gmail.com
}

Received 20 June 2015; accepted 25 July 2015; published 28 July 2015

Copyright (C) 2015 by authors and Scientific Research Publishing Inc.

This work is licensed under the Creative Commons Attribution International License (CC BY). http://creativecommons.org/licenses/by/4.0/ c) (i) Open Access

\section{Abstract}

In the present study, a biofertilizer on the basis of Streptomyces fumanus gn-2 was used for the treatment of wheat and soybean seeds (dose $10^{4} \mathrm{spore} / \mathrm{ml}$ ) before planting them in soil with low fertility in order to determine the effect of this biological agent on germination rate; the growth of seedlings, shoots, and the maturation phase of plants; the rhizosphere's functional biodiversity; and the resistance of these plants to pathogens. Seeds were soaked in the suspension for a period of two or three hours. During the growing season of the crop, no additional fertilizing and spraying of a biopesticide against diseases or pests occurred. Despite the soil having low fertility, low quantities of organic matter, and not having been before used for the cultivation of agricultural plants, this biofertilizer showed a strong stimulatory effect on the growth of seeds and seedlings of wheat and soybeans. The average germination and seed vigor increased by $1.5-2.0$ times, and the phenophases were accelerated to three to five days. In all phases of vegetation, the ammonifying bacteria in the presence of an antagonist (a biological agent) developed rapidly and were constantly present in significant numbers in the rhizosphere. Streptomyces fumanus introduced into nonsterile soil entered into competition with the local soil microflora and had the ability to colonize the rhizosphere system of plants. The use of a formulation of Streptomyces gn-2 has improved the composition of rhizosphere microflora, attracting saprophytic microorganisms: ammonificators and oligotrophs. The presence of the biocontrol microorganism Streptomyces fumanus in the rhizosphere plays an important role in enhancing the growth and development of useful groups, such as nitrogen-fixing bacteria.

\section{Keywords}

A Low Fertility Soil, A Biofertilizer, Streptomyces fumanus gn-2, Wheat and Soybean Seeds, Stimulatory Effect on Seed Germination, Rhizosphere's Functional Biodiversity

How to cite this paper: Doolotkeldieva, T., Bobusheva, S. and Konurbaeva, M. (2015) Effects of Streptomyces Biofertilizer to Soil Fertility and Rhizosphere's Functional Biodiversity of Agricultural Plants. Advances in Microbiology, 5, 555-571. 


\section{Introduction}

Kyrgyzstan is a unique country with a rich natural and agro-biodiversity. Kyrgyzstan has great potential for organic farming. There are large ecologically clean areas, which can be converted to organic farming in a relatively short transition period. Kyrgyzstan as a niche, therefore, is the most suitable area for the cultivation of ecologically clean and tasty products, and obtaining stable yields.

Productivity of agricultural plants depends on the quality and condition of the seeds that carry the genetic potential for cultivation, representing great value for growers and producers of agricultural products. They also carry a significant amount of energy, which makes them very attractive to pests and diseases [1]. It is known that seed distributes over $30 \%$ of all crop pathogens, which cause significant deterioration to the sowing qualities of seeds, reduced vigor and germination, inhibiting the growth and development of seedlings and their root systems. The most vulnerable period of development is the phase of seed germination-emergence. Therefore, it is important to solve the health problems of seeds via the creation of a biofertilizer with a twofold effect: a biofungiside and a growth regulator that reduces the toxic load of using chemical fungicide for seed treatment.

A biological seed treatment agent is an important prerequisite for profitable crop production, and to obtain a complete and environmentally sound crop. Some of the potential bioagents that are employed for the management of soil fertility and seed protection act as biofertilizers [2]. When biofertilizers are applied to seed, plant surfaces, or soil, they colonize the rhizosphere or the interior of the plant, promoting growth by increasing the supply or availability of primary nutrients to the host plant. If fertilizers directly increase soil fertility by adding nutrients, biofertilizers add nutrients through the natural processes of fixing atmospheric nitrogen, solubilizing phosphorus, and stimulating plant growth through the synthesis of growth promoting substances [3]. Biofertilizers are capable of positively influencing plant growth as biostimulants, and, at the same time, enabling the reduction of fertilizer rates, because of their very low application doses. The most frequent effects induced by biostimulants are an improved activity of soil microbiota [4]; an increased production of growth regulators in both soil [5] and plants [6] [7]; and increased root development, which favors the absorption of nutrients [8]-[10]. In plants, biostimulants stimulated numerous metabolic pathways [11]-[14]. Specifically, a cellulosolytic apple hydrolysate and a blueberry extract have been shown to increase maize growth via the induction of nitrogen and phenylpropanoid pathways, which increased photosynthetic efficiency [15]. Moreover, biostimulated crops are also less sensitive to stressful conditions (drought, extreme temperatures, excessive moisture in the rhizosphere, and over- or under-exposure to light and salinity) [16] [17] due to their high production of anti-oxidant compounds [18]. In fact, the maximum efficiency of a biostimulant occurs at very low dosages and is dependent on plant species, cultivars, and the vegetative phase [15] [19] [20] [21]. The majority of studies on the effects of biostimulants in plants involve short-term experiments with seed germination and young plantlet growth, and little information is available on the maturity phase [9] [12] [22]. There are different groups of microorganisms used as biofertilizers: Azotobacter, Rhizobium, Azospirillum, Bacillus megaterium var. phosphaticum, Bacillus circulans, Pseudomonas striata, Pseudomonas fluorescens, Arbuscular mycorrhiza, Trichoderma viride, Trichodermaharzianum, Bacillus subtilis, and others [3].

Soil bacteria belonging to the Streptomycetes are regarded as promising biocontrol organisms due to their potential to produce a vast array of secondary substances such as vitamins, alkaloids, plant growth factors, enzymes, and enzyme inhibitors [23]-[25]. They are capable of exhibiting beneficial as well as detrimental effects on plants, including promotion of symbiosis, improved growth, abiotic stress resistance, and an enhanced resistance to fungi and bacterial diseases. Studies even show that use of Streptomyces enhances growth of the crop plants [26].

In the present study, we have used a biofertilizer created in our laboratory (Patent \# 1703, registered by 10/12/2012 in the State Register of Kyrgyz Republic) on the basis of Streptomyces fumanus gn-2 for the treatment of wheat and bean seeds, before planting them in soil with low fertility in order to determine the effect of this biological agent on germination rate, growth of seedlings and shoots, maturation phase of plants, rhizosphere functional biodiversity, and resistance of these plants to pathogens.

\section{Materials and Methods}

\subsection{Preliminary Modeling Experiments}

For modeling experiments two types of soil: black earth and meadow gray soil were used for seed growing in 
the pots.

Black earth soil characteristics: A1 horizon, firm sod, brownish-black, powdery-granular structure. Its power is in the range of $10-15 \mathrm{~cm}$. This soil contains up to $10 \%-15 \%$ of humus. Reaction of upper horizons is neutral orslightly acid. Soil absorbing complex is saturated with calcium and magnesium. Organic total carbon-3.93\%; total nitrogen-0.36\%; C:N-10.5.

Meadow gray soil characteristics: Mechanical composition is silt-loam, sandy loam, and loamy less. The humus content- $-7 \%-1.7 \%$; total nitrogen-0.1\% $-0.14 \%$. They are calcareous to the surface: the $\mathrm{CO}_{2}$ in the upper layer is about 2\% - 3\%. C:N-6.3. Mechanical fraction \%: $1.0-0.25 \mathrm{~mm}-5.34 ; 0.25-0.05 \mathrm{~mm}-17.5$.

\subsection{Site Characteristics and Experimental Layout}

In 2008, the experimental field of the Agricultural Faculty was established on the territory of the Jal Campus of Kyrgyz-Turkish Manas University, with $80 \%$ sand, 9\% silt, and 11\% clay (in topsoil) and containing significant different metals-Mn, Ni, Co, Ti, Cr, Mo, W, Zr, Nb, Cu, Pb, Ag, Sb, Z, Cd, Sn, In, Ga, Yb, Y, La, Ce, P, Sr, Be, Ba, Li, Sc, Hf, Ta, Th, U, Pt, and Au. These soils have not previously been used as farmland. A continuous application of composted farmyard cattle manure with a $5 \mathrm{~cm}$ layer of black soil without mineral fertilizer was conducted for three years (2008-2011). The farmyard cattle manure was composted for six months before application. The $\mathrm{pH}$ of the soil was 6.3 and its organic carbon content was $0.5 \%-0.7 \%$. In the future, this research field will be used only for the purpose of organic farming.

\subsection{Seed Treatment}

For seed treatment was used the biofertilizer, that contains the cells and spores of Streptomyces fumanus gn-2 strain (genus Streptomyces) (Figure 1). Streptomyces fumanus gn-2 was obtained from the rhizosphere of mustard (Sinapis alba) in the Issuk-Kul region of Kyrgyzstan. The 16S rRNA genes of Streptomyces fumanus were PCR amplified with 27f and 1522r primers, polyketide synthase (PKS) genes were screened by polyketidesynthetase primers [27] [28].

The biofertilizer is available in liquid form and the liquid concentrate contains at least $3 \times 10^{9}$ cells $/ \mathrm{ml}$ of living cells and spores of Streptomyces fumanus. It has a dirty cream with a pinkish hue and peculiar smell. This product is bottled into $100 \mathrm{ml}, 250 \mathrm{ml}, 500 \mathrm{ml}$, and $1000 \mathrm{ml}$ capacities, ready for application. The biofertilizer's trade name is "Rostin”. It is completely safe and non-toxic to humans, animals, and insects.

Different working concentrations of biofertilizer were prepared depending on the size and species of seed plants. Seeds were soaked in the suspension for periods of two and three hours. The seeds were dried after

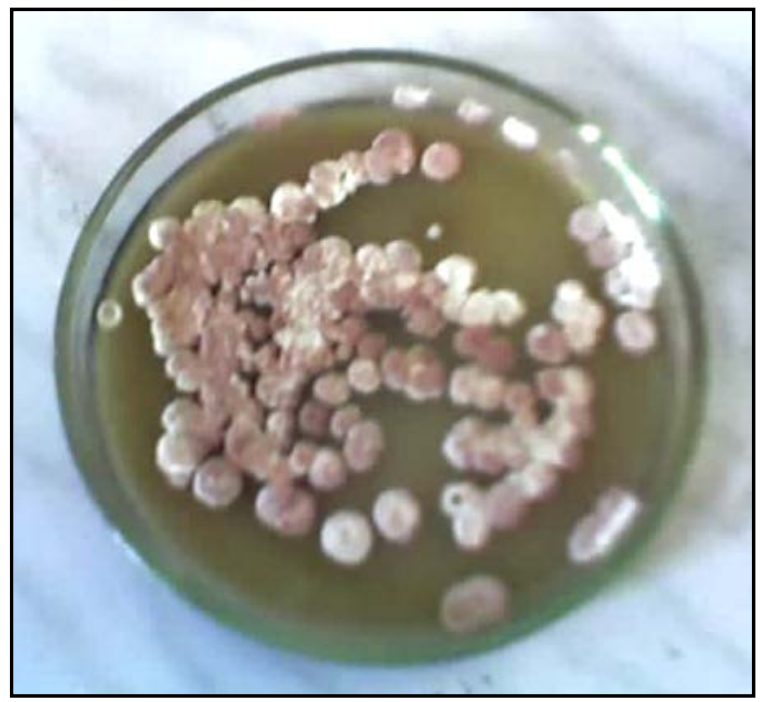

(a)

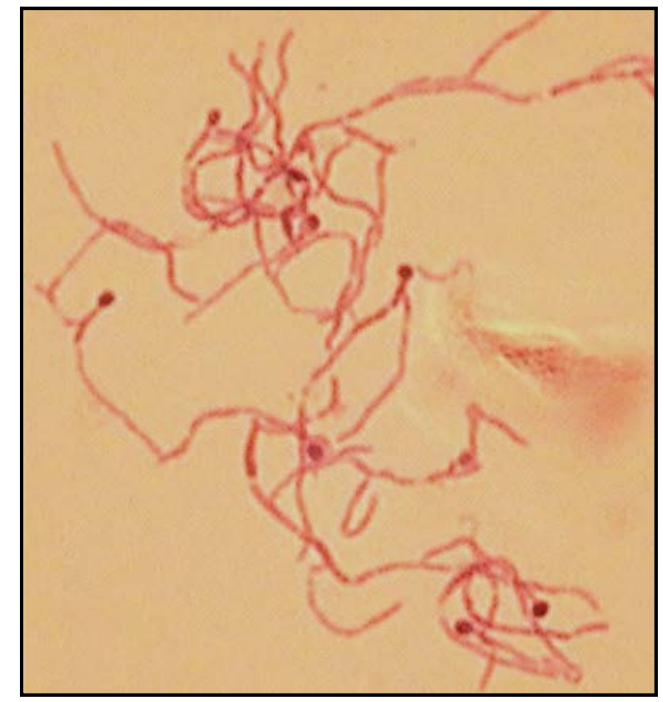

(b)

Figure 1. (a) Aerial mycelium pure culture strain gn-2 on starch-ammonia medium; (b) Microscopic picture of mycelium and spores at $\times 100$. 
treatment in the shade, and then the light-dried seeds were planted in soil, making sure the same amount of the suspension was used for soaking of seeds. Each concentration was tested in three replicates. Control seeds were treated with sterile water.

Records of the results were taken daily for the vegetation period. This takes into account the seed germination and seed viability, the length of the root system and stems, and weight of their biomass.

The most optimal term of use of this biofertilizer is the period when the temperature of soil is a minimum of $15^{\circ} \mathrm{C}-17^{\circ} \mathrm{C}$ and the air is $20^{\circ} \mathrm{C}$. This condition not only allows the development of mycelium and spores of Streptomyces fumanus, but also allows the development of seeds and organisms in soil, in order that the antibiotic substances produced by mycelia can prevent infection, penetrating from the soil through the emerging lateral roots of seedlings. Another necessity is that it outpaces the development of pathogenic fungi through the actions of growth-stimulating substances to ensure the rapid growth of the root system and stalks.

A biological (technical) efficiency of biofertilizer was calculated by the formula:

$$
E=100-\frac{b}{a} \times 100
$$

where $E$ is the effectiveness of reducing damage relative to a control; $a$ is the damaged plants in the control; $b$ isthe damaged plants in the experiment.

Seedling vigor index $=$ mean seedling length $(\mathrm{cm}) \times$ germination percentage $(\%)$.

Differences between groups of means were obtained using the Student-Newman-Keuls test at $\mathrm{P} \leq 0.05$. All statistics were formulated by use of SPSS software version 19 [29].

\section{Results and Discussion}

\subsection{Preliminary Modeling Experiments}

Two types of soil: black earth and meadow gray soil were used for seed growing. Two different doses: $10^{-6}$ and $10^{4}$ cells/ml of Streptomyces fumanus biofertilizer were used for seed treatment. To determine the optimal exposure time of soaking, the seeds were soaked in a suspension of Streptomyces fumanus biofertilizer for three hours, six hours, and 12 hours. The results of screening showed that a dose of $10^{4}$ cells/ml of biofertilizer had the best bio-stimulating effect on shoots of wheat and soybeans in the meadow gray soil than in black earth soil. The optimal time of seed soaking in a suspension of biofertilizer was three hours (Table 1).

The investigated dose of Streptomyces fumanus biofertilizer has showed a clearly expressed growth-stimulating effect when the seeds were growing in meadow gray soils.

Apparently, this is due to the fact that the gray soils contain high heavy minerals (from $2 \%$ to $10 \%$, and more). In addition, along with a high content of micas, these soils are rich in various bases and ash plant nutrition elements. The germination rate of wheat and soybean seeds were sufficiently higher in gray soils than in black soil. So, when the seeds were treated with Streptomyces fumanus bioproduct the germination vigor of wheat seeds made of $100 \%$ on day 10 , when using the standard chemical biostimulants (indoleacetic acid, IAA) $-85 \%$, in control, with water- $80.9 \%$. Whereas in black soil the germination vigor of wheat seeds was achieved only at $45 \%$, when the seeds were treated with Streptomyces fumanus bioproduct, with the application of standard chemical stimulator-47\%, in controls-25\% (P $\geq 0.05)$.

Table 1. Growth stimulating effect of Streptomyces fumanus biofertilizer on seeds and seedlings of agricultural crops in gray meadow soils $(n=3)$.

\begin{tabular}{lcccc}
\hline Dose cells/ml & Germination, in, \% & The length of the stem, $\mathrm{mm}$. & Root length, mm & The total biomass in, $g$ \\
\hline & & Wheat & \\
Streptomyces fumanus gn-2, $10^{4}$ & 100 & $164.0 \pm 0.37$ & $142.0 \pm 0.15$ & $23.32 \pm 0.47$ \\
Control, water & 82.0 & $93.0 \pm 0.65$ & $65.0 \pm 0.54$ & $15.25 \pm 0.53$ \\
& & Soybean & $150.0 \pm 0.19$ & $29.86 \pm 0.43$ \\
Streptomyces fumanus gn-2, $10^{4}$ & 98.0 & $95.0 \pm 0.38$ & $90.0 \pm 0.15$ & $27.42 \pm 0.27$ \\
\hline
\end{tabular}


After these model experiments, where it was evident that Streptomyces fumanus biofertilizer showed a large effect on seed germination and the sprouting development of wheat and soybeans by using $10^{4} \mathrm{cell} / \mathrm{ml}$, the experiments were transferred to field conditions in low fertile gray soil, with low organic matter content (Figure 2(a), Figure 2(b), Figure 3(a), Figure 3(b)).

\subsection{Field Experiments}

\subsubsection{Biotests of Streptomyces fumanus Biofertilizeron Spring Wheat Varieties}

An optimization method of using biofertilizer is to reduce the wastage of bioproducts and increasing the domestic economic effect of microbiological protection. These requirements are satisfied by the low-volume method of soaking the seeds in a suspension formulation, in which a high concentration of working suspension is created that improves the penetration ability of the mycelium and the active compounds into cells of growing seedlings and saplings. In addition, the low-volume method of spraying a working suspension of liquid formulation provides a uniform coverage on the surface of plant organs, which reduces the period of the death of phytopathogens and increases the effectiveness of the fight.

The following spring wheat varieties were tested: variety №302 Jawahir-21; variety №304 Abier-8; variety №311 Rabih-1; variety №316 Babaga-3; variety №319 Baasha-2; variety №321 Baasha-18; variety №323 Aseel-7; variety №324 National check; and variety №308 Qimma-8 (from CIMMYTL: The International Maize and Wheat Improvement Center). Each variety has two variants: a control where the seeds were planted without soaking in water, and a test version where the seeds were treated with a suspension of a biological product "Rostin” $\left(10^{4}\right.$ cells/ml). The width of the beds was one meter. Spacing was $35 \mathrm{~cm}$, in triplicate, with 100 grains being placed per logging site.

\subsubsection{Biometric Indicators of Spring Wheat on Phases of Vegetation Plants}

The high productivity of plants is determined by the process of photosynthesis, growth, and movement of nutrient

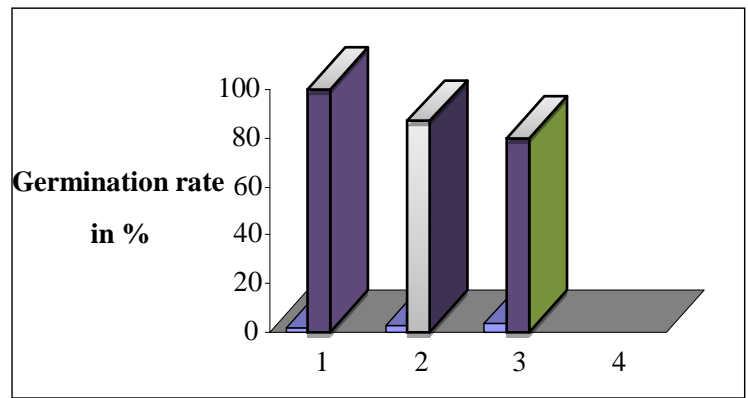

(a)

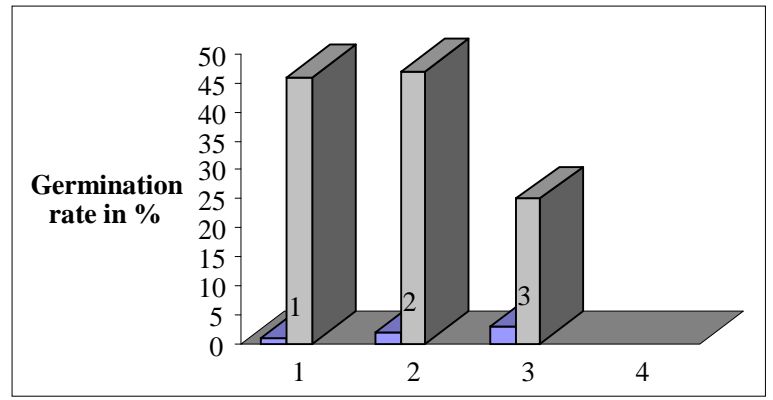

(b)

Figure 2. (a) Germination vigor rate of wheat seeds on grey soil; (b) Germination vigor rate of wheat seeds on black soil: 1-Strep. biofertilizer; 2-standart chemical biostimulator; 3-control, water.

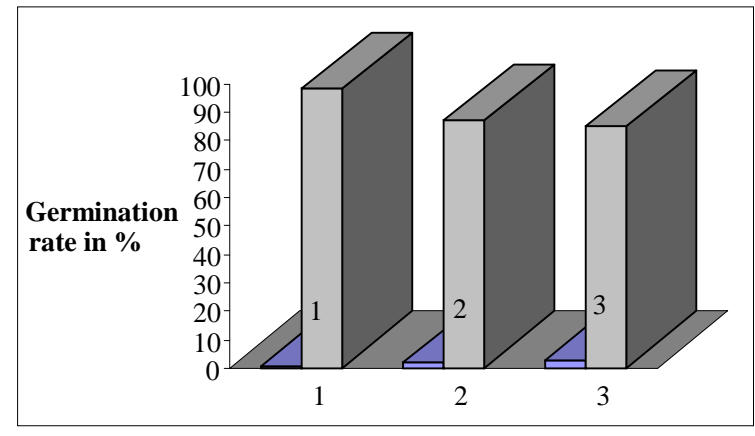

(a)

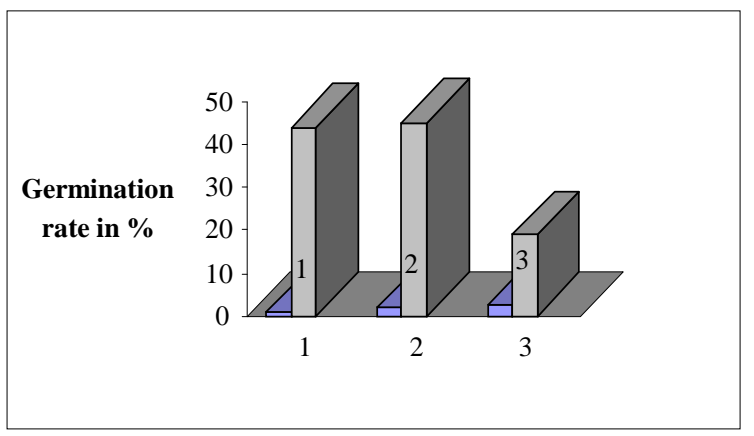

(b)

Figure 3. (a) Germination vigor rate of beans seeds on grey soil; (b) Germination vigor rate of beans seeds on black soil: 1-Strep. biofertilizer; 2 -standart chemical biostimulator; 3-control, water. 
substances. An indicator of high morphological potential opportunities on which depend the productivity of plants is the quantity of photosynthetic organs [30] [31]. A significant difference in height and till ring of plants between the control and test variants was not observed in the sprouting phase, except forvariety №317 Raaid-3, variety №319 Baasha-2, and variety №322 Baasha-24, which were marked by significant differences in the length of the stems when compared to other varieties. In plots treated with biological fertilizer, the wheat sprouts were $1-1.2 \mathrm{~cm}$ longer than those of the control plants (Table 2).

As shown by the biometric indicators in the phase of tillering, many varieties in the plots treated with biofertilizer have a $1.2-2.0 \mathrm{~cm}$ higher growth of aboveground organs than in the control variant (Table 3).

In the heading stage, many varieties of wheat plants treated with the biological product were advanced in growth when compared to the untreated plants. So, variety №302 Jawahir-21 by $4.0 \mathrm{~cm}$; variety Abier-8-by 3.7 cm; variety №311 Rabih-1 by 2.7 cm; variety №316 Babaga-3 by $3.3 \mathrm{~cm}$; variety №323 Aseel-7 by $1.3 \mathrm{~cm}$; and variety №324 National check by $3.3 \mathrm{~cm}$ were longer than control plants (Table 4).

The ability of plants to absorb the solar energy, according to some researchers, argely depends on the plant height, which determines the accumulation of dry matter and the final harvest value [32].

In the phase of maturation except the plant height, such important factors as the number of spikelets and the number of grains per plant were taken into account. If, before this phase, we have evaluated the effectiveness of biofertilizer only on the height of plants and general tillering, in this last phase the productivity of experimental field was assessed by determining the number of spikelets and the number of grains per plant (Table 5).

Table 2. Biometric characteristics of wheat in the shoot phase $(n=3)$.

\begin{tabular}{|c|c|c|c|c|}
\hline № & A variety denomination & Variants & Plant height, $\mathrm{cm}$ & Total tillering, pcs/plant \\
\hline \multirow{2}{*}{1} & \multirow{2}{*}{ №317 Raaid-3 } & Control & $4.0 \pm 1.07$ & 1 \\
\hline & & Treated & $6.0 \pm 1.07$ & 2 \\
\hline \multirow{2}{*}{2} & \multirow{2}{*}{ №319 Baasha-2 } & Control & $5.0 \pm 1.07$ & 2 \\
\hline & & Treated & $6.3 \pm 1.3$ & 2 \\
\hline \multirow{2}{*}{3} & \multirow{2}{*}{ №312 Rabih-8 } & Control & $3.3 \pm 1.07$ & 1 \\
\hline & & Treated & $4.0 \pm 0.61$ & 1 \\
\hline \multirow{2}{*}{4} & \multirow{2}{*}{ №322 Baasha-24 } & Control & $4.5 \pm 1.07$ & 1 \\
\hline & & Treated & $5.3 \pm 1.3$ & 1 \\
\hline
\end{tabular}

Table 3. Biometric characteristics of wheat in the phase of tillering $(n=3)$.

\begin{tabular}{|c|c|c|c|c|c|}
\hline № & A variety denomination & Variants & Plant height, cm & Total tillering, pcs/plant & Productive tillering, pcs/plant \\
\hline \multirow{2}{*}{1} & \multirow{2}{*}{ №302 Jawahir-21 } & Control & $11.3 \pm 0.37$ & 2 & 2 \\
\hline & & Treated & $13.8 \pm 0.61$ & 1 & 1 \\
\hline \multirow[t]{2}{*}{2} & №304.Abier-8 & Control & $10.8 \pm 0.37$ & 1 & 1 \\
\hline & & Treated & $12.5 \pm 1.07$ & 1 & 1 \\
\hline \multirow[t]{2}{*}{3} & №311 Rabih-1 & Control & $13.5 \pm 1.3$ & 1 & 1 \\
\hline & & Treated & $14.7 \pm 1.07$ & 1 & 1 \\
\hline \multirow[t]{2}{*}{4} & №316 Babaga-3 (Check) & Control & $7.3 \pm 0.37$ & 1 & 1 \\
\hline & & Treated & $9.7 \pm 0.61$ & 1 & 1 \\
\hline \multirow[t]{2}{*}{5} & №323 Aseel-7 & Control & $12 \pm 1.3$ & 1 & 1 \\
\hline & & Treated & $14 \pm 1.07$ & 1 & 1 \\
\hline \multirow[t]{2}{*}{6} & №324 National check & Control & $11.7 \pm 0.61$ & 1 & 1 \\
\hline & & Treated & $12.7 \pm 1.3$ & 1 & 1 \\
\hline
\end{tabular}


Table 4. Biometric characteristics of wheat in the phase of heading $(n=3)$.

\begin{tabular}{|c|c|c|c|c|c|}
\hline № & A variety denomination & Variants & Plant height, $\mathrm{cm}$ & Total tillering, pcs/plant & Productive tillering, pcs/plant \\
\hline \multirow{2}{*}{1} & \multirow{2}{*}{ №302 Jawahir-21 } & Control & $48.7 \pm 1.3$ & 2 & 2 \\
\hline & & Treated & $52.0 \pm 1.07$ & 1 & 1 \\
\hline \multirow[t]{2}{*}{2} & №304Abier-8 & Control & $30.7 \pm 0.07$ & 3 & 2 \\
\hline & & Treated & $34.0 \pm 1.3$ & 1 & 1 \\
\hline \multirow[t]{2}{*}{3} & №311 Rabih-1 & Control & $44.0 \pm 1.07$ & 1 & 1 \\
\hline & & Treated & $46.7 \pm 2.25$ & 1 & 1 \\
\hline \multirow[t]{2}{*}{4} & №316 Babaga-3 (Check) & Control & $34.3 \pm 1.3$ & 1 & 1 \\
\hline & & Treated & $37.0 \pm 1.07$ & 1 & 1 \\
\hline \multirow[t]{2}{*}{5} & №323 Aseel-7 & Control & $32.7 \pm 1.07$ & 1 & 1 \\
\hline & & Treated & $34.0 \pm 1.3$ & 1 & 1 \\
\hline \multirow[t]{2}{*}{6} & №324 National check & Control & $46.7 \pm 1.07$ & 3 & 2 \\
\hline & & Treated & $50.0 \pm 2.25$ & 3 & 2 \\
\hline
\end{tabular}

Table 5. Biometric characteristics of wheat in the phase of maturation $(n=3)$.

\begin{tabular}{|c|c|c|c|c|c|c|}
\hline № & A variety denomination & Variants & $\begin{array}{l}\text { Plant height, } \\
\mathrm{cm}\end{array}$ & $\begin{array}{c}\text { Total tillering, } \\
\text { pcs/plant }\end{array}$ & $\begin{array}{c}\text { Productive tillering, } \\
\text { pcs/plant }\end{array}$ & $\begin{array}{l}\text { Number of grains } \\
\text { per plant, pieces }\end{array}$ \\
\hline \multirow[t]{2}{*}{1} & №308 Qimma-8 (Check) & Control & $38.7 \pm 1.08$ & $7.7 \pm 1.07$ & 13 & 126 \\
\hline & & Treated & $41.7 \pm 4$ & $8.3 \pm 0.05$ & 16 & 147 \\
\hline \multirow[t]{2}{*}{2} & №310 N-Abyad-16 & Control & $49.7 \pm 1.06$ & $7.3 \pm 1.08$ & 14 & 122 \\
\hline & & Treated & $53 \pm 1.04$ & $8 \pm 0.05$ & 15 & 167 \\
\hline \multirow[t]{2}{*}{3} & №312 Rabih-8 & Control & $45 \pm 1.7$ & $7.7 \pm 1.07$ & 15 & 136 \\
\hline & & Treated & $49 \pm 2.67$ & $8 \pm 1.08$ & 15 & 144 \\
\hline \multirow[t]{2}{*}{4} & №316 Babaga-3 (Check) & Control & $44.3 \pm 1.01$ & $8.3 \pm 0.05$ & 15 & 145 \\
\hline & & Treated & $49.7 \pm 1.03$ & $8.7 \pm 1.07$ & 15 & 156 \\
\hline \multirow[t]{2}{*}{5} & №317 Raaid-3 & Control & $52.7 \pm 2$ & $8 \pm 1.07$ & 15 & 138 \\
\hline & & Treated & $56 \pm 1.05$ & $7.7 \pm 1.09$ & 15 & 148 \\
\hline \multirow[t]{2}{*}{6} & №324 National check & Control & $30.3 \pm 1.03$ & $6 \pm 1.07$ & 13 & 97 \\
\hline & & Treated & $42 \pm 0.07$ & $6.7 \pm 0.09$ & 15 & 111 \\
\hline
\end{tabular}

As Table 5 shows, the number of grains per plant in those treated with biological product variant were greater than in the control. Thus, our study has revealed a positive correlation between the height of the plants in various phases of development and yield of grain: in the tillering phase $\left(r=0.34, \mathrm{Sr}= \pm 0.17, \mathrm{r}^{2}=0.12, \mathrm{tr}=2.01\right.$ when $\mathrm{t} 05=2.0)$, in the rearing phase $\left(\mathrm{r}=0.61 \pm 0.15, \mathrm{r}^{2}=0.37, \mathrm{tr}=4.2\right.$ at $\left.\mathrm{t} 05=2.0\right)$, and in the phase of maturation ( $\mathrm{r}$ $=0.51 \pm 0.16, r^{2}=0.26$, tr $=3.2$ at $t 05=2.0$ ). In the flowering phase, correlation was insignificant. Processing the wheat seeds with biofertilizer before sowing them has had a significant impact on the increase in plant height in different phases of their growth and development.

In some varieties, the growth stimulating effect of biofertilizer was demonstrated more strongly, and in others such efficiency was almost non-evident.

Dynamics of rhizosphere microflora of spring wheat on phases of vegetation in the application of biofertilizer. Soil quality is directly linked to biodiversity of soil microorganisms, as their metaboliccap abilities are linked to 
most of the soil's functions, such as nutrient cycling [33] [34]. The ability of soilmicroorganisms to catabolizearange of different organic substrates is known as the community level physiological profile [35]-[37], giving information on those involved in the carboncycle [38]. The "insurance hypothesis" predicts that only certains pecies are essential for ecosystem functioning under steady state conditions, where as the main part is involved in the stabilization processes in the case of changing environments (Loreau et al., 2001).

A rhizosphere microflora of spring wheat in shoot, till ring, and maturation phases was investigated. Population density of species and biodiversity physiological groups: ammonificators, oligotrophs and diazotrophs was studied. To identify the impact of Streptomyces fumanus on the formation of wheat rhizosphere microflora we compared these organisms in the experimental, control variants and bulk soil.

\subsection{Number and Biodiversity of Ammonificators by the Phases of Wheat}

In the shoot phase the number of ammonificators in wheat rhizosphere microflora was low, whereas in bulk soil the number of these bacteria was 1.5-fold higher. In the till ring phase the number of ammonificators in the rhizosphere was almost 1.2 - 1.5 fold higher than in the shoot phase. In this phase, in the control variant the number of these bacteria was higher than in the treated with Streptomyces fumanus variant and in bulk soil.

The density of ammonificators population has increased with the plants ripening. In the maturation phase, the number of bacteria in bulk soil was $47.6 \pm 0.97 \times 10^{3} \mathrm{CFU} / \mathrm{g}$. soil $(\mathrm{P} \geq 0.05)$, while in the control and the variant with Streptomyces fumanus their number was equal and made of $64 \pm 1.23 \times 10^{3} \mathrm{CFU} / \mathrm{g}$. soil ( $\mathrm{P} \geq 0.05$ ) (Figure 4(a), Figure 4(b)).

Usually the ammonificators get nutrient and energy due to the decomposition of fresh organic matter in the root system of plants. Low numbers of these bacteria in the shoot phase, apparently, to be related to the fact that the growing, young root hairs produced a small number of exudates, which are source of nutrient for the bacteria living in the rhizosphere. With the development of lateral roots, the amount of organic secretions is increased to attract micro-organisms. So, the biological agent as Streptomyces fumanus does not stimulate the growth of ammonificators in the rhizosphere. But this agent does affect the species composition of the rhizosphere thus causing a shift in functional groups of rhizobacteria.

16S ribosomal RNA analysis revealed a rich biodiversity of rhizosphere bacteria in the maturation phase. In the rhizosphere microflora of wheat the ordinary saprophytic bacteria of different phylum were dominated: $\mathrm{Mi}$ crobacterium hydrocarbonoxydans, Microbacterium oxydans, Microbacterium sp. VKM Ac-2051, Curtobacterium sp. VKM Ac-2061, Klebsiella pneumoniae, Erwinia sp. Xb2, Uncultured bacterium, Actinomycete P032, Brevibacterium sp. Halomonas sp. Below we have indicated only biodiversity of Microbacterium genus (Figure $5)$.

\subsection{Number and Biodiversity of Oligotrophs by the Phases of Wheat Vegetation}

In the shoot phase, their number in the version with Streptomyces fumanus was $2.6 \pm 0.75 \times 10^{3} \mathrm{CFU} / \mathrm{g}$ of soil, and in the till ring it was even less-only $1.80 \pm 0.56 \times 10^{3} \mathrm{CFU} / \mathrm{gr}$ soil, and by the end of the growing period,

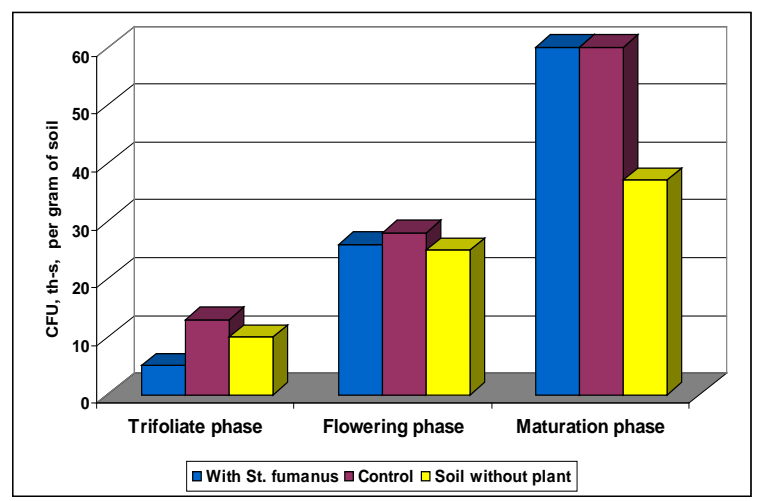

(a)

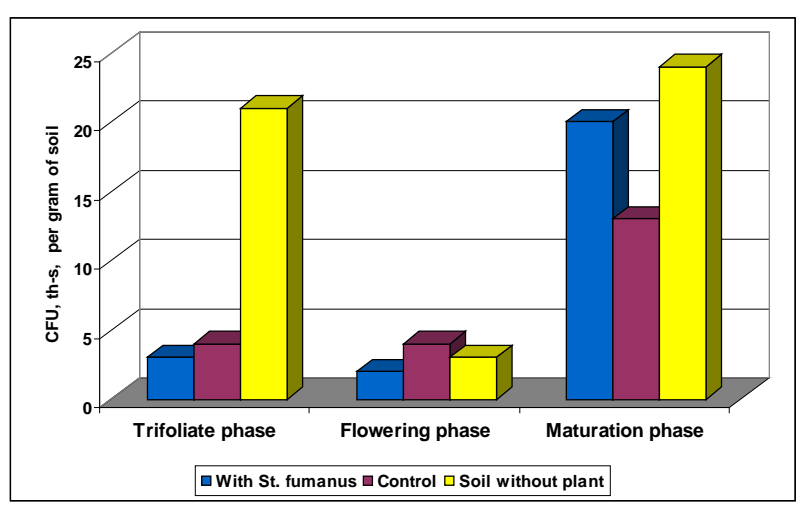

(b)

Figure 4. (a) The number of ammonificators in the rhizosphere of wheat at different vegetation phases; (b) The number of oligotrophs in the rhizosphere of wheat at different stages of vegetation. 


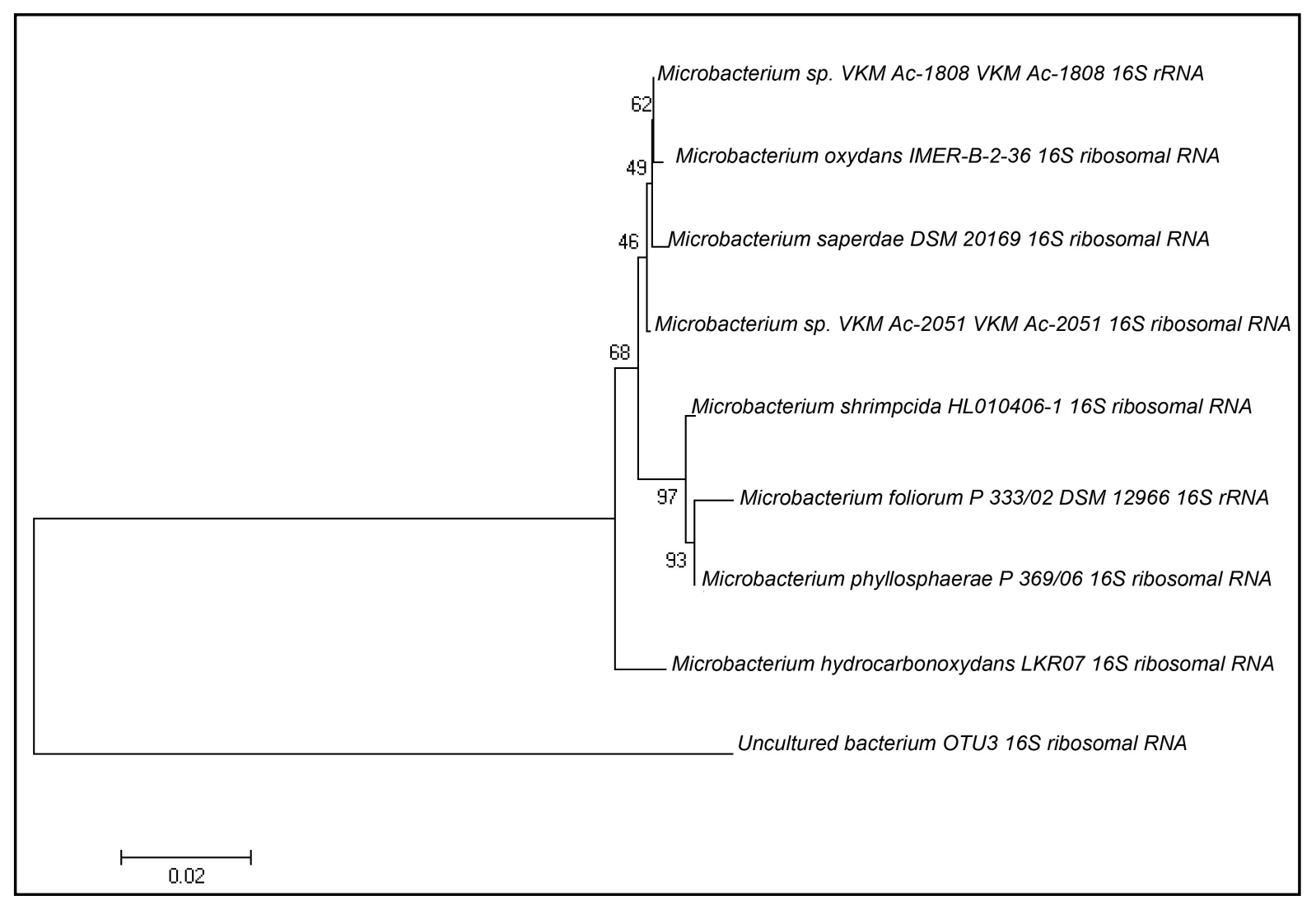

Figure 5. Neighbour-joining phylogenetic tree based on 16SrRNA gene sequences showing the position of isolated bacteria strains fromwheat rhizosphere.

their number increased dramatically, reaching up to $21.6 \pm 1.23 \times 10^{3} \mathrm{CFU} / \mathrm{g}$ of soil. In the control the number of actinomycetes in the shoot and in the till rings phases was the same, and in the maturation phase it has doubled and amounted to $12.4 \pm 0.89 \times 10^{3} \mathrm{CFU} / \mathrm{g}$. soil. In bulk soil we have revealed a high number of colony-forming units in the shoot and maturation phases, their number reached up $23.6 \pm 0.79 \times 10^{3} \mathrm{CFU} / \mathrm{g}$ of soil, and in the till ring stage it is decreased by 4 times (Figure 4(b)).

Biodiversity of actinomycetes was represented by species from the Actinobacteria phylum: Streptomyces fumanus, Arthrobacter sp., Dermacoccus profundi, Rhodococcus sp., Actinobacterium OR-26 and others. In the variant, where was used the biological product, Streptomyces fumanus was isolated during all growing season. This indicates to the survival ability of this culture in the rhizosphere of wheat (Figure 6).

\subsection{The Number and Biodiversity of Nitrogen-Fixing Bacteria on Growth Stages of Wheat}

In contrast to other microorganisms in the rhizosphere of wheat nitrogen fixing bacteria have shown significant number at allphases of plant development, particularly where it was applied a Streptomyces fumanus product. So, the presence of biocontrol microorganism - Streptomyces fumanus - in the rhizosphere plays an important role not only in the suppression of pathogenic species but enhances growth and development of useful groups, such as nitrogen-fixing bacteria. The population densities and the diversity of the root microflora had affected the number and activity of Azotobacter bacteria, which may contribute to additional nitrogen inputs to the soil (Figure 7).

\subsection{Biotests of Streptomyces fumanus Biofertilizeron Soybeans Varieties}

Two varieties of soybeans: Seeds of local "Amantay" variety and imported seeds from other countries "Danko" variety were used in field experiments. In microplot experiments, two variants were placed: a control where the seeds were planted after soaking in water, and a test version where the seeds were treated with suspension of a 


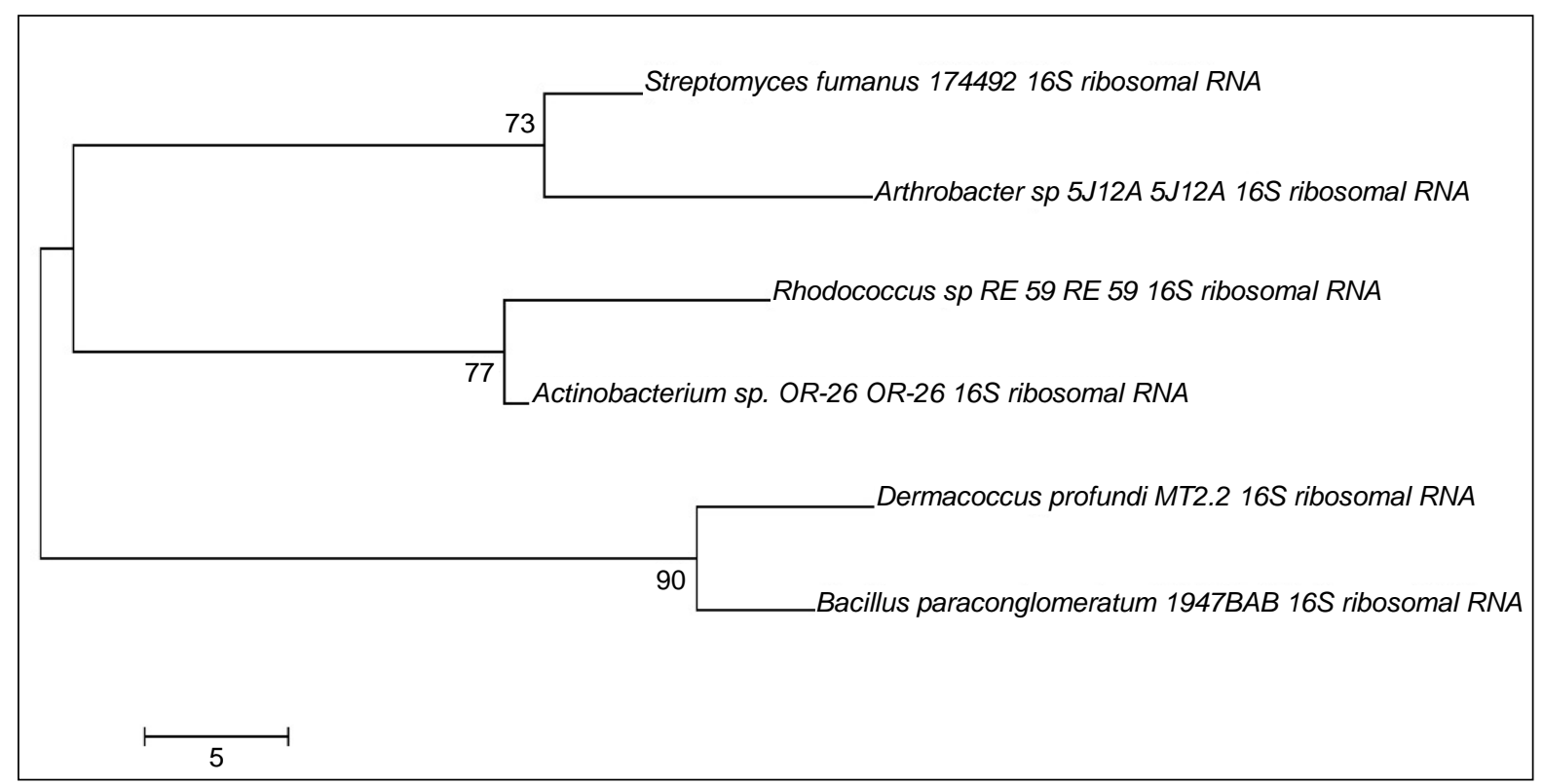

Figure 6. Neighbour-joining phylogenetic tree based on 16SrRNA gene sequences showing the position of isolated bacteria strains from wheat rhizosphere (with a biologic product).

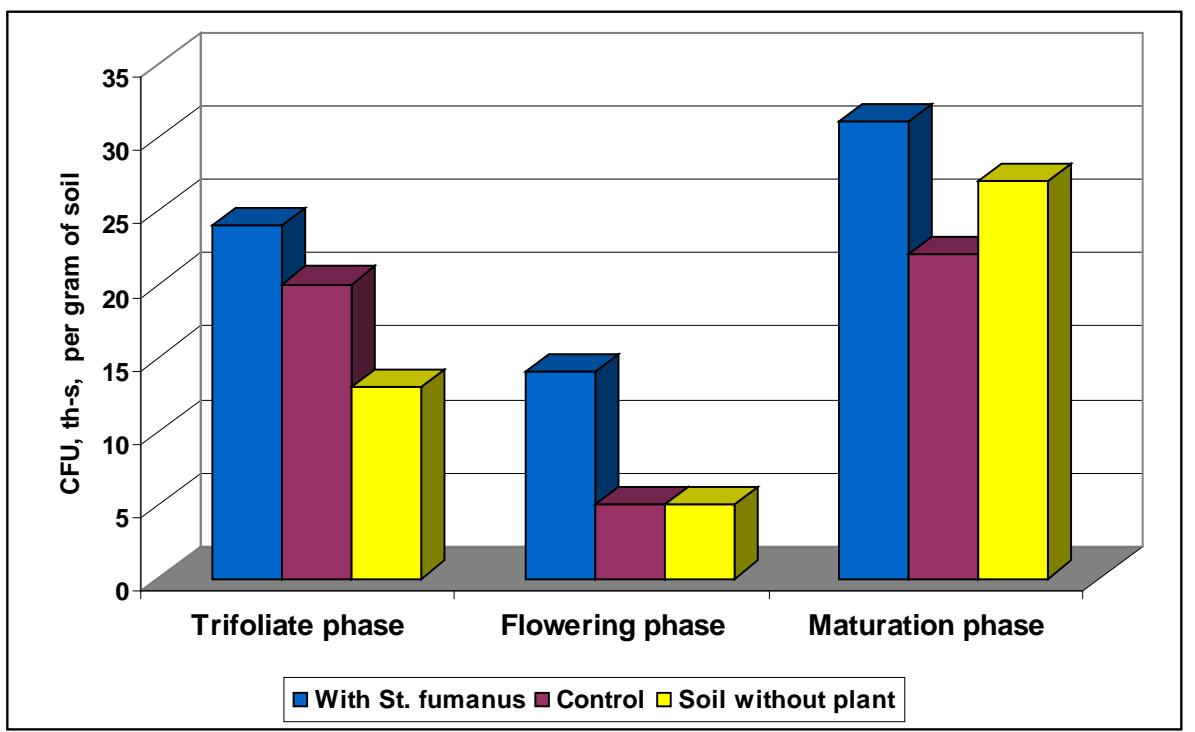

Figure 7. The number of nitrogen-fixing bacteria in the rhizosphere of wheat at different stages of vegetation, in \%.

biological product "Rostin” ( $10^{4}$ cells $\left./ \mathrm{ml}\right)$. The width of the beds was $60 \mathrm{~cm}$, with a seeding rate of $1 \mathrm{~kg} / 1$ acre of land, repeated twice. Soybeans were seeded on 21 May, and harvested on 4 September.

The stimulating effect of a biological product was already evident in the early phases of plant development. As the results of phenological observations (Table 6), the seedlings germinated from seeds treated with biofertilizer and growing shoots were two times longer than in the control variant in all phases of development.

In addition, the plants germinated from seeds treated with "Rostin" differed invigor, tillering, and flowering. The treated plants started flowering four to five days earlier than in the control. Visually, cropshada difference in morphological features; for example, they were different in the color saturation of leaves, the treated leaves were in dark green color, while in the control the leaves were in light green color. Root and stem lengths were 1.2 times higher in treated version than in the control. The use of a biofertilizer has increased a above ground and underground mass of plants. The root weight of treated specimens was $10 \pm 0.32 \mathrm{~g} / 10$ plants and in the control 
variant it was $8.5 \pm 0.56 \mathrm{~g} / 10$ plants.

Analys is of grain biomass also showed a positive effect on the formation of "Rostin" to soybean crop. Weight of 1000 seeds on the plots with biofertilizer was considerably greater than the weight of 1000 seeds obtained in the control variant: the excess was between $5.0 \%$ and $11.0 \%$ (Table 7 ).

The number of pods treated with "Rostin" was 1.9 - 2 times greater than in the control. The use of biofertilizer also has contributed to a more powerful development of the root system and to seeds' weight. Beans were bigger in the test variant, than in the control.

Dynamics of the rhizosphere microflora of soybeanon phases of vegetation. The rhizosphere microflora of soybean in three phases: in the formation of first trifoliate leaf, flowering and maturation was explored.

Number and biodiversity of ammonificators by the phases of soybean. In all phases of the growing season the ammonificators bacteria in the presence of a biological agent—Streptomyces—-have developed rapidly and were constantly in significant density (Figure 8(a)). This suggests that a balance is created between the rhizosphere inhabitants due to Streptomyces culture that produced the growth stimulating compounds enhancing a cell division and differentiation of root hairs. This results in increasing the number of lateral root hairs and in growing the nutritional and respiratory surface root system. It shows once more that Streptomyces cells and mycelium are well take root in the rhizosphere; do not exhibit an inhibitory effect on the development of saprophytic bacteria.

Table 6. Biometric characteristics of soybean in phases of development.

\begin{tabular}{cccc}
\hline \multirow{2}{*}{ Experimental variants } & \multicolumn{3}{c}{ The length of the shoots of plants in phases of development, cm } \\
\cline { 2 - 4 } & The shoots at the beginning of branching & Flowering & The emergence of beans \\
\hline Control (water) variety “amantay" & $3.3 \pm 0.73$ & $7 \pm 0.34$ & $29.9 \pm 0.58$ \\
Control (water) variety “danko" & $3.5 \pm 0.71$ & $6.9 \pm 0.52$ & $28.3 \pm 0.43$ \\
Biofertilizer, "rostin” variety “amantay" & $5.9 \pm 0.65$ & $10 \pm 0.76$ & $33.9 \pm 0.86$ \\
Biofertilizer,"rostin"variety “danko" & $5.7 \pm 0.62$ & $9.8 \pm 0.37$ & $33.0 \pm 0.42$ \\
\hline
\end{tabular}

Table 7. Biostimulator effect of biofertilizer on the structure and quality of the harvest of soybeans $(n=3)$.

\begin{tabular}{ccccc}
\hline Experimental variants & $\begin{array}{c}\text { Stem length, } \\
\mathrm{cm}\end{array}$ & $\begin{array}{c}\text { Length of roots, } \\
\mathrm{cm}\end{array}$ & $\begin{array}{c}\text { Number of podsper plant, } \\
\text { pieces }\end{array}$ & $\begin{array}{c}\text { Weight of } \\
1000 \text { seeds g }\end{array}$ \\
\hline Control (water) variety “amantay” & $40.7 \pm 0.87$ & $10.9 \pm 0.95$ & 10 & $89.8 \pm 1.05$ \\
Control (water) variety “danko" & $38.5 \pm 0.23$ & $9.7 \pm 0.82$ & 10 & $88.8 \pm 1.03$ \\
Biofertilizer, "rostin” variety “amantay” & $60.8 \pm 0.92$ & $15.3 \pm 0.91$ & 20 & $100.8 \pm 1.02$ \\
Biofertilizer, "rostin” variety “danko" & $60.7 \pm 0.90$ & $15.2 \pm 0.87$ & 20 & $100.2 \pm 1.0$ \\
\hline
\end{tabular}

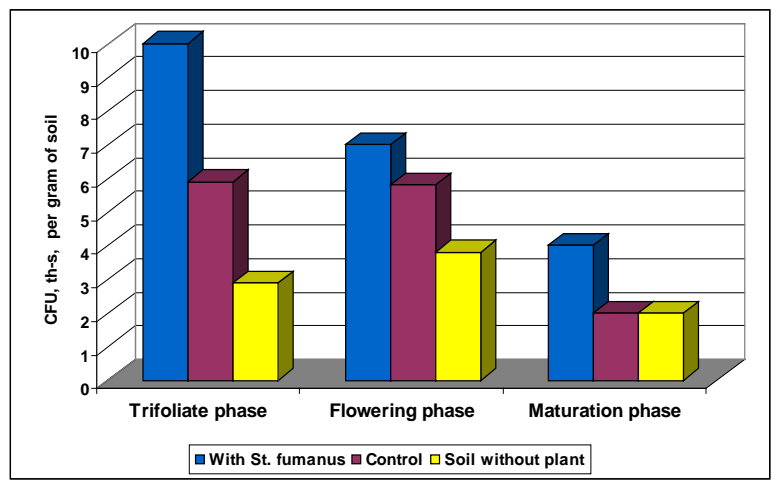

(a)

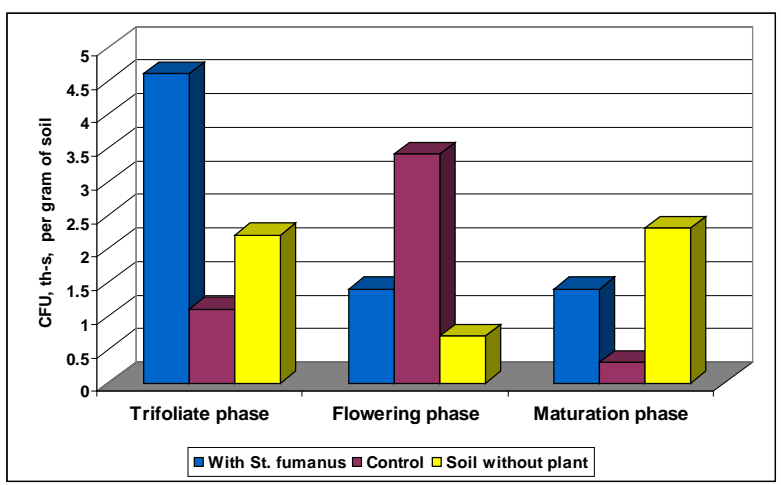

(b)

Figure 8. (a) The number of ammonificators in the rhizosphere of soybean at different stages of vegetation; (b) The number of actinomycetes in the rhizosphere of soybean at different vegetation phases. 
16S ribosomal RNA analysis has revealed the biodiversity of bacteria that make up the rhizosphere microflora of the soybean in the till ring phase in the control variant. The true rhizosphere species from Flavobacteriia phylum: such as Chryseobacterium sp. RBA2, Chryseobacterium sp. QT2, Elizabethkingia sp., Candidatus Chryseobacterium massiliae, Trichloroacetic-acid-degrading bacterium, uncultured bacterium and the othergroups of bacteria were dominated (Figure 9).

PCRassay foundcompletely different species of ammonificators in the variant with biological product. So, bacteria from Bacteroidetes phylum were dominated: Pedobacter borealis,Pedobacter kribbensis, Pedobacter agri, Pedobacter terrae, Bacteroidetes bacterium 7-11, Sphingobacteriaceae bacteriumand Flavobacterium sp (Figure 10).

$16 \mathrm{~S}$ rRNA analyses from bulk soil has detected mainly spore forming bacteria, mainly representatives of Firmicutes phylum: Bacillus aryabhattai, Bacillus subtilis, Bacillus horikoshii, Bacillus pumilus, Bacillus flexus, Bacillus megaterium and Bacterium LWA-2-2 (Figure 11).

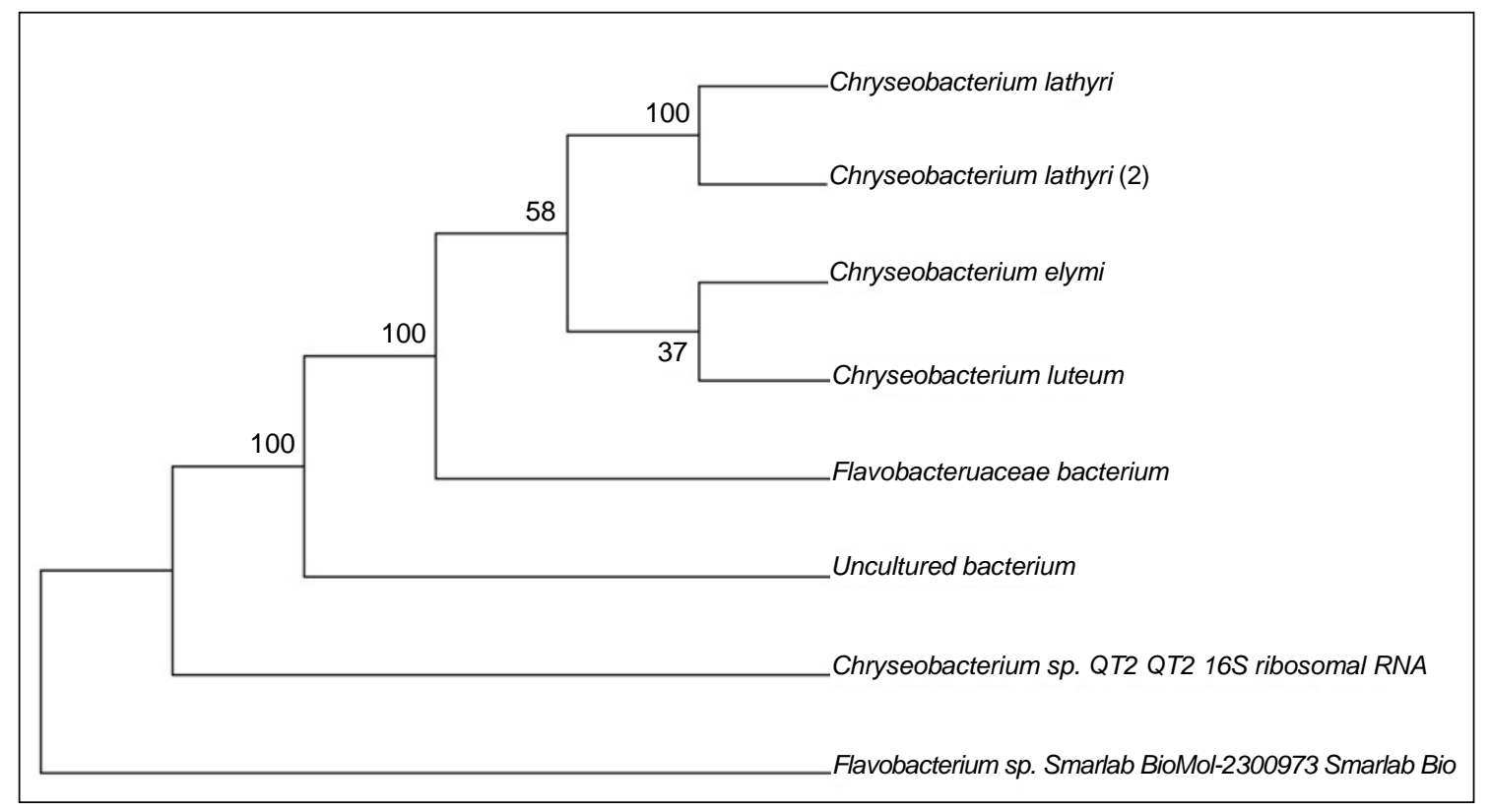

Figure 9. Neighbour-joining phylogenetic tree based on 16S rRNA gene sequences showing the position of isolated bacteria strains from soybean rhizosphere in control variant.

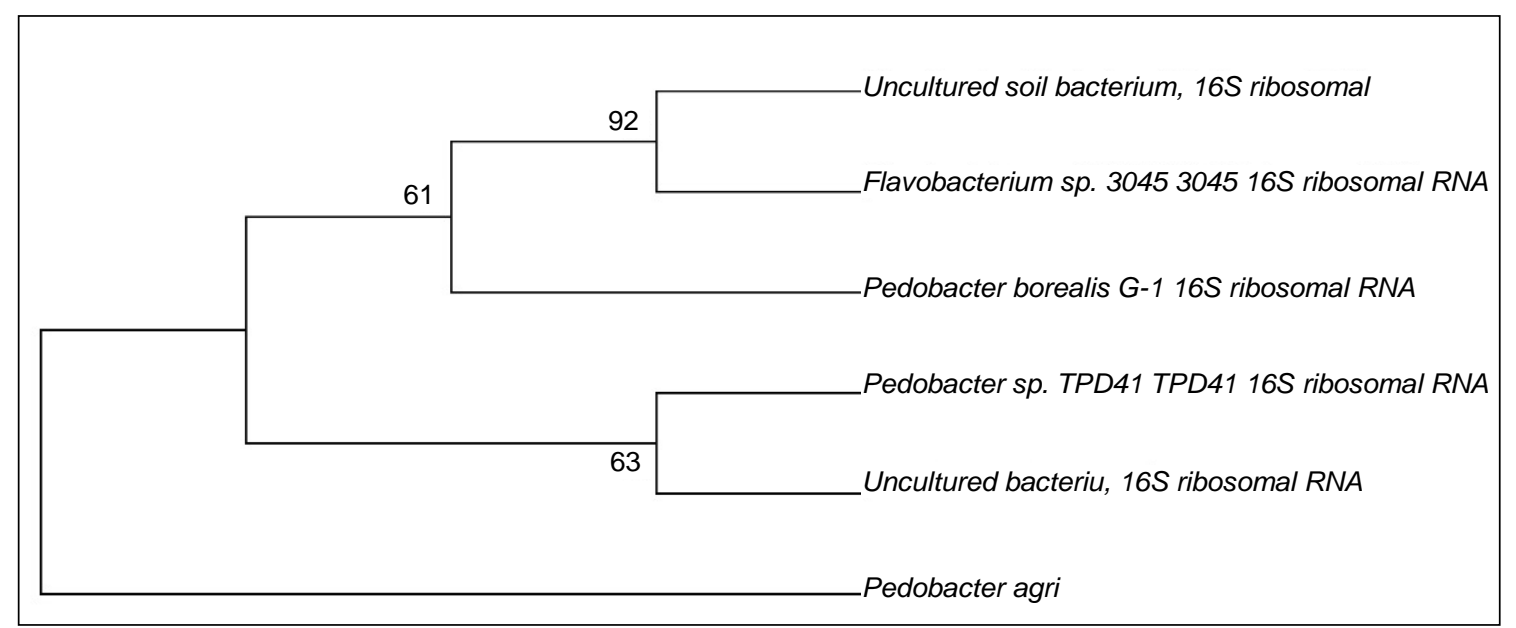

Figure 10. Neighbour-joining phylogenetic tree based on 16SrRNA gene sequences showing the position of isolated bacteria strains from soybean rhizosphere in experimental variant. 


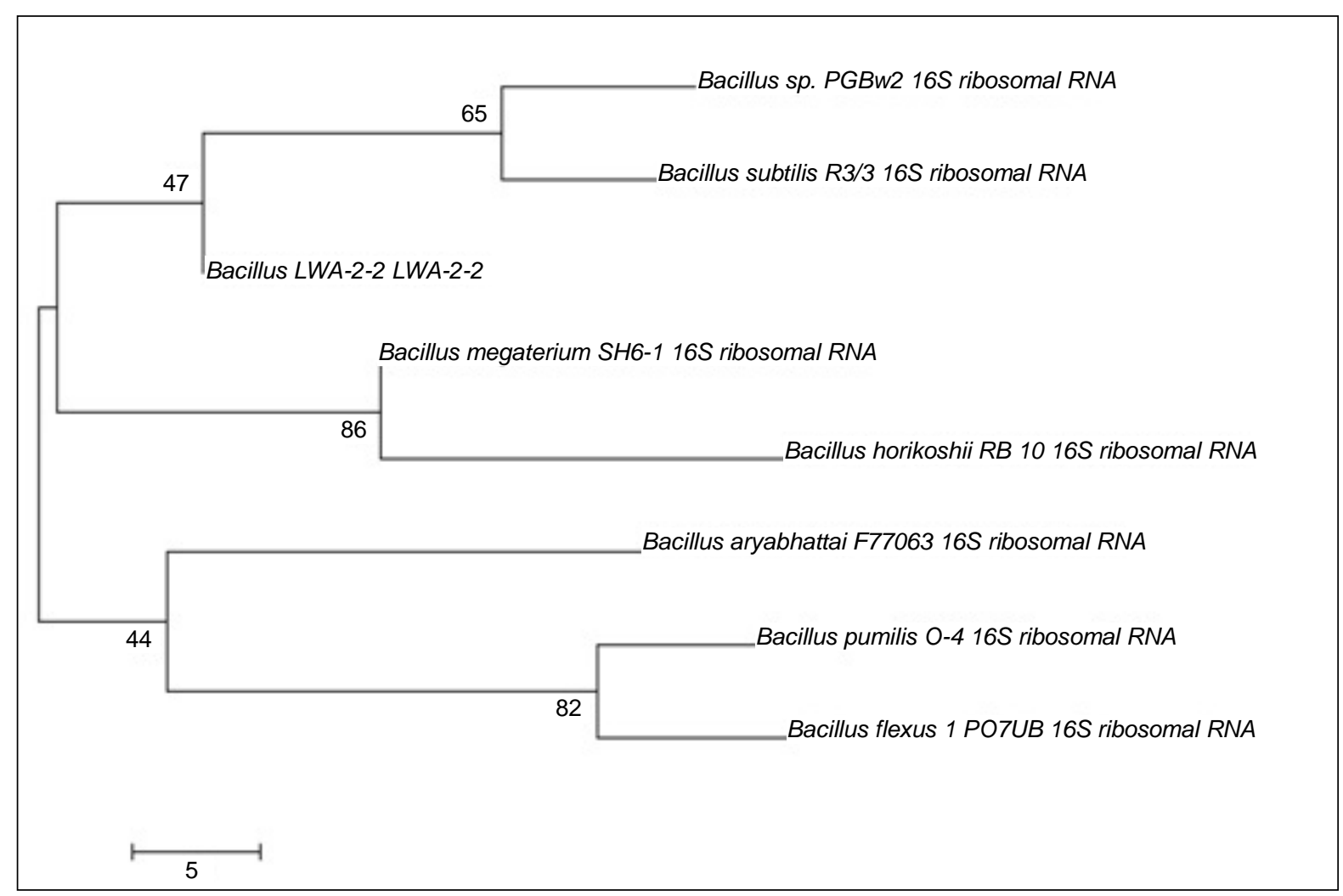

Figure 11. Neighbour-joining phylogenetic tree based on 16SrRNA gene sequences showing the position of isolated bacteria strains from soybean rhizosphere in bulk soil.

Number and biodiversity of oligotrophs by the phases of soybean vegetation. The number of colony-forming units of actinomycetes was high in the tillering phase and at the end of the growing season remained in significant amount where was used biofertilizer. These figures indicate that the culture of Streptomyces fumanus, which is the basis of a biological product survives perfectly among other species of Streptomyces in the root zone of soybean, reproducing intensively it has reached the significant quantities there (Figure 8(b)).

The number and biodiversity of nitrogen-fixing bacteria on growth stages of soybean. The influence of Streptomyces fumanus on the dynamics of nitrogen-fixing bacteria was evident. In the flowering phase the number of nitrogen fixers increased by 2 fold higher than in bulk soil. In the maturation phase, the density of nitrogen fixers also has remained stable and relatively high (Figure 12).

Thus, as the results have shown, the effects of Streptomyces fumanus on the rhizosphere microflora of wheat (Triticum aestivum) differed from that of soybean (Glycine max) by phases of plant development. In the shoot phase of wheat we observed a marked refraining effect of the biological agents on the development of ammonifiers in the rhizosphere. Only at the maturation phase their amount equaled to control, which indicates that a balance among bacteria forming rhizosphere communities of wheat was established. Whereas the ammonifiers in the presence of a biological agent developed rapidly and remained constantly in significant numbers in all phases of soybeans.

$16 \mathrm{~S}$ ribosomal RNA analysis revealed a rich biodiversity of bacteria in the rhizosphere of wheat maturation phase, which differs from the biodiversity of bacteria in the rhizosphere of soybean in the same phase. Bacteria of Microbacterium genus from Actinobacteriaphylum were dominated in the rhizosphere of wheat. The bacteria species of Chryseobacterium genus from Flavobacteriia phylum were dominated in the rhizosphere of soybean that proves a different chemical composition of these organic plant exudates attracting the preferred species of microorganisms.

The degree of Streptomyces fumanus survival in the rhizosphere of soybean was stable and higher than in the rhizosphere of wheat. So, at the end of vegetation in the variant treated with biologic agent the number of actinomycetes in the soybean rhizosphere was much higher than in the control and bulk soil. 


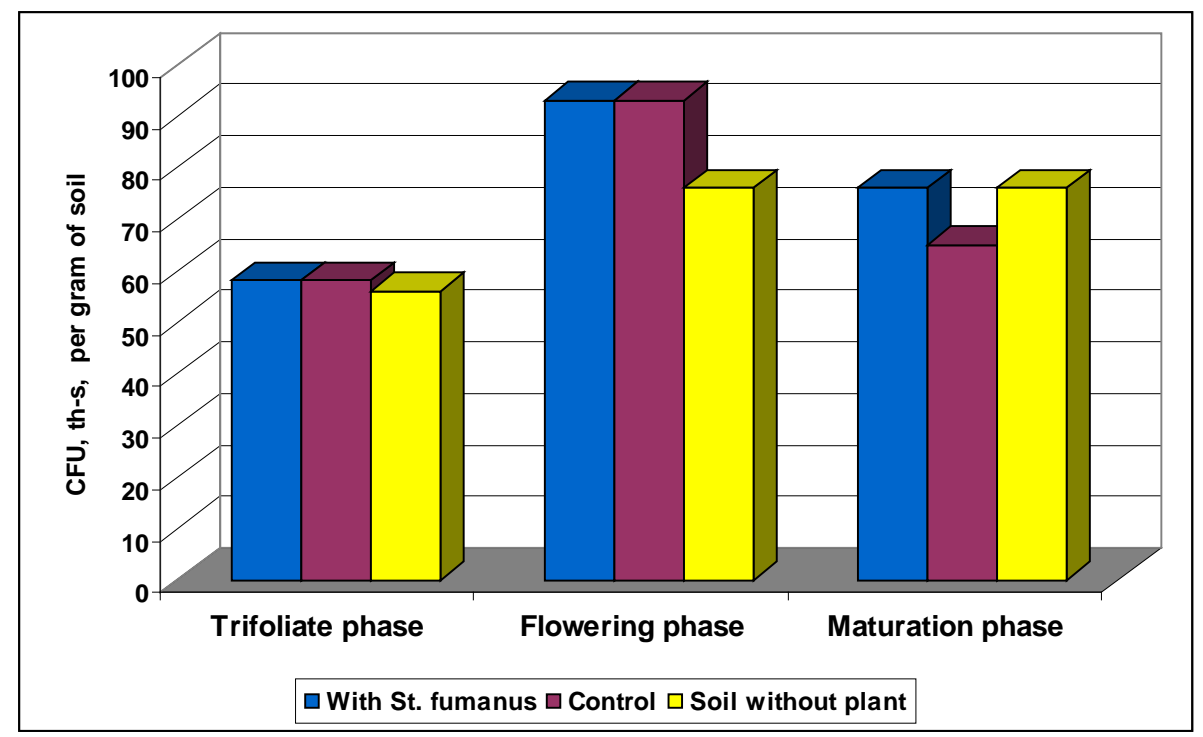

Figure 12. The number of colony-forming units of nitrogen-fixing bacteria in the rhizosphere of soybean at different vegetation phases.

The results have allowed to confirm that Streptomyces fumanus is an ideal biological agent for use against soil infections, due to its high colonization of the root system of soybeans and a significant colonization of wheat. Streptomyces fumanus introduced into non-sterile soil had entered into competition with the local soil microflora and had the ability to colonize the rhizosphere system of plants. Using Streptomyces fumanus through the seeds has improved the composition of the soil microflora, attracting saprophyticrhizosphere microorganisms.

\section{Discussion}

Streptomyces fumanus isolated from the rhizosphere, as a biofertilizer was intended for seed and soil application to increase plant growth and to protect from pathogens in this study.

The biofertilizers have to have success criteria for wide application: they have to be effective in actual field conditions, in a range of soils and in different host cultivars. Despite the low soil fertility and lack of irrigation water in summer period a treatment of seeds by Streptomyces fumanus product has shown the growth stimulatory effect on all phases of soybean and ultimately has increased a biomass and grain yield overall.

In all phases of vegetation, the ammonifying bacteria in the presence of an antagonist (a biological agent) developed rapidly and were constantly present in significant numbers in the rhizosphere. This indicates some balance created between the rhizosphere inhabitants and the Streptomyces fumanus biological agent. It can be assumed that Streptomyces fumanus produced growth-stimulating compounds such as auxin and cytokinins, which could enhance cell division and differentiation of root system, increasing the number of lateral root hairs, and consequently increase the nutritional and respiratory surfaces of the root system as a whole.

The healthier root hairs are emitting the exudates more intensively, which are food for saprophytic bacteria. Cells and mycelium Streptomyces fumanus have taken root in the rhizosphere, showing no inhibitory effect on the development of saprophytic bacteria.

In general, there was no marked fungal infection in the root system of plants; there was not a single case of plant disease in the soybean crop area, despite the low content of organic matter in the soil. Root exudates of soybeans provide a nutritional base for the growth of antagonistic organisms, which plays an important role in controlling not only the soil phytopathogens, but also contributes to the active functioning of a very important group-nitrogen-fixing bacteria in the rhizosphere.

The results have confirmed that the introduction of Streptomyces fumanus as a biological agent in soil together with the seeds has stimulated the growth and reproduction of useful and important for the soil environment microorganisms. The rhizosphere can therefore be considered as a microbiological buffer zone, in which the microfloraserves to protect the plants from the attack of pathogens and to improve soil fertility.

Thus, the results have obtained from experiment all and that was not previously used as farmland lead us to 
the following conclusions:

- The enrichment and density of soil microorganisms were low in the studied experimental area and represented a poor biodiversity of microflora.

- Streptomyces fumanus introduced into non-sterile soil entered into competition with the local soil microflora and had the ability to colonize the rhizosphere system of plants.

- The use of a formulation of Streptomyces gn-2 had improved the composition of rhizosphere microflora, attracting saprophytic microorganisms: ammonificators and oligotrophs.

- The presence of the biocontrol microorganism Streptomyces fumanus in the rhizosphere plays an important role in enhancing the growth and development of useful groups, such as nitrogen-fixing bacteria.

- The use of the Streptomyces fumanus as a biological agent hastened phenophases for three to five days, and increased the height of the plants and the size of the leaf blades, creating a hostile environment for the development of weeds and phytopathogens.

- Results of field experiments have showed that seed treatment by a biological agent has increased seedling height and length of the spine, compared with the control plants.

- Treatment of seeds by a biologicalfertilizer such as Streptomyces gn-2 is an important prerequisite for profitable crop production and obtaining a full and environmentally healthy crop.

- Treatment of seeds by biologicalfertilizer protects the culture, ranging from seed to plant, and provides the optimal stand density, minimum consumption of seeds (one seed = one plant).

- Treatment allows us to significantly reduce the load on the environment.

- Using the biological fertilizer for the pre-processing of seeds provides the healthy shoots of plants even at a relatively high level of seed infection.

- The productivity of cereals increased by $20 \%$, and soybeans by $30 \%$.

\section{References}

[1] ISTA (1996) International Rules for Seed Testing. Seed Science and Technology, 13, 299-513.

[2] Mogle, U.P. and Mane, R.Y. (2010) Antagonistic Effect of Biofertilizers against Seed Borne My Coflora of Tomato (Lycopersicum esculentum). Research Journal of Agricultural Sciences, 1, 255-258.

[3] Bharathi, V., Sudhakar, R., Parimala, K. and Reddy, V.A. (2013) Evaluation of Bioagents and Biofertilizers for the Management of Seed and Seedling Diseases of Sesamum indicum (Sesame). eSci Journal of Plant Pathology, 2, 179186.

[4] Corte, L., Dell’Abate, M.T., Magini, A., Migliore, M., Felici, B., Roscini, L., et al. (2014) Assessment of Safety and Efficiency of Nitrogen Organic Fertilizers from Animal-Based Protein Hydrolysates-A Laboratory Multidisciplinary Approach. Journal of the Science of Food and Agriculture, 94, 235-245. http://dx.doi.org/10.1002/jsfa.6239

[5] Frankenberger, W.T. and Arshad, M. (1995) Phytormones in Soils. Marcel Dekker Inc., New York, 35-71.

[6] Jindo, K., Martim, S.A., Navarro, E.C., Pérez-Alfocea, F., Hernandez, T., Garcia, C., et al. (2012) Root Growth Promoting by Humic Acids from Composted and Non-Composted Urban Organic Wastes. Plant and Soil, 353, 209-220. http://dx.doi.org/10.1007/s11104-011-1024-3

[7] Pizzeghello, D., Francioso, O., Ertani, A., Muscolo, A. and Nardi, S. (2013) Isopentenyladenosine and Cytokinin-Like Activity of Different Humic Substances. Journal of Geochemical Exploration, 129, 70-75. http://dx.doi.org/10.1016/j.gexplo.2012.10.007

[8] Canellas, L.P., Olivares, F.L., Okorokova-Facanha, A.L. and Facanha, A.R. (2002) Humic Acids Isolated from Earthworm Compost Enhance Root Elongation, Lateral Rootemergence, and Plasma Membrane $\mathrm{H}^{+}$-ATPase Activity in Maize Roots. Plant Physiology, 130, 1951-1957. http://dx.doi.org/10.1104/pp.007088

[9] Nardi, S., Pizzeghello, D., Muscolo, A. and Vianello, A. (2002) Physiological Effects of Humic Substances on Higher Plants. Soil Biology \& Biochemistry, 34, 1527-1536. http://dx.doi.org/10.1016/S0038-0717(02)00174-8

[10] Khan, W., Rayirath, U.P., Subramanian, S., Jithesh, M.N., Hodges, D.M., Critchley, A.T., et al. (2009) Seaweed Extracts as Biostimulants of Plant Growth and Development. Plant Growth Regulation, 28, 386-399. http://dx.doi.org/10.1007/s00344-009-9103-X

[11] Nardi, S., Muscolo, A., Vaccaro, S., Baiano, S., Spaccini, R. and Piccolo, A. (2007) Relationships between Molecular Characteristics of Soil Humic Fractions and Glycolytic Pathway and Krebs Cycle in Maize Seedlings. Soil Biology and Biochemistry, 39, 3138-3146. http://dx.doi.org/10.1016/j.soilbio.2007.07.006

[12] Nardi, S., Carletti, P., Pizzeghello, D. and Muscolo, A. (2009) Biological Activities of Humic Substances. In: Senesi, N., Xing, B. and Huang, P.M., Eds., Biophysico-Chemical Processes Involving Natural Nonliving Organic Matter in 
Environmental Systems. Part I. Fundamentals and Impact of Mineral-Organic-Biota Interactions on the Formation, Transformation, Turnover, and Storage of Natural NonlivingOrganic Matter (NOM), John Wiley \& Sons, Hoboken, 305-339. http://dx.doi.org/10.1002/9780470494950.ch8

[13] Schiavon, M., Ertani, E. and Nardi, S. (2008) Effects of an Alfalfa Protein Hydrolysate on the Gene Expression and Activity of Enzymes of TCA Cycle and N Metabolism in Zea mays L. Journal of Agricultural and Food Chemistry. 172, 237-244.

[14] Ertani, A., Nardi, S. and Altissimo, A. (2012) Review: Long-Term Research Activity on the Biostimulant Properties of Natural Origin Compounds. Acta Horticulturae, 1009, 181-188.

[15] Ertani, A., Schiavon, M., Altissimo, A., Franceschi, C. and Nardi, S. (2011) Phenol-Containing Organic Substances Stimulate Phenylpropanoid Metabolism in Zea mays. Journal of Plant Nutrition and Soil Science, 3, 496-503. http://dx.doi.org/10.1002/jpln.201000075

[16] Marfà, O., Cáceres, R., Polo, J. and Ródenas, J. (2009) Animal Protein Hydrolysate ASA Biostimulant for Transplanted Strawberry Plants Subjected to Cold Stress. Acta Horticulturae, 842, 315-318.

[17] Ertani, A., Schiavon, M., Muscolo, A. and Nardi, S. (2013) Alfalfa Plant-Derived Biostimulant Stimulate Short-Term Growth of Salt Stressed Zea mays L. Plants. Plant and Soil, 364, 145-148. http://dx.doi.org/10.1007/s11104-012-1335-Z

[18] Lakhdar, A., Iannelli, M.A., Debez, A., Massacci, A., Jedidi, N. and Abdelly, C. (2010) Effect of Municipal solid Waste Compost and Sewage Sludge Use on Wheat (Triticum durum): Growth, Heavy Metal Accumulation, and Antioxidant Activity. Journal of the Science of Food and Agriculture, 90, 965-971. http://dx.doi.org/10.1002/jsfa.3904

[19] Nardi, S., Pizzeghello, D., Remiero, F. and Rascio, N. (2000) Chemical and Biochemical Properties of Humic Substances Isolated from Forest Soils and Plant Growth. Soil Science Society of America Journal, 64, 639-645. http://dx.doi.org/10.2136/sssaj2000.642639x

[20] Zhang, X., Ervin, E.H. and Schmidt, R.E. (2003) Effects of Liquid Application of a Seaweed Extract and a Humic Acid on Creeping Bentgrass (Agrostis palustris Huds. A.). Journal of the American Society for Horticultural Science, 128, 492-496.

[21] Kaufmann III, G.L., Kneivel, D.P. and Watschke, T.L. (2007) Effects of a Biostimulant on the Heat Tolerance Associated with Photosynthetic Capacity, Membrane Thermostability, and Polyphenol Production of Perennial Ryegrass. Crop Science, 47, 261-267. http://dx.doi.org/10.2135/cropsci2006.03.0171

[22] Rose, M.T., Patti, A.F., Little, K.R., Brown, A.L., Jackson, W.R. and Cavagnaro, T.R. (2014) A Meta-Analysis and Review of Plant-Growth Response to Humic Substances: Practical Implications for Agriculture. Advances in Agronomy, 124, 37-89. http://dx.doi.org/10.1016/B978-0-12-800138-7.00002-4

[23] Lehr, N.A., Schrey, S.D., Hampp, R. and Tarkka, M.T. (2008) Root Inoculation with a Forest Soil Streptomycete Leads to Locally and Systemically Increased Resistance against Phytopathogens in Norway Spruce. New Phytologist, 177, 965-976. http://dx.doi.org/10.1111/j.1469-8137.2007.02322.x

[24] Abd Allah, N.A. and El-Mehalawy, A.A. (2002) Antifungal Producing Actinomycetes as Biocontrol Agents for Plant Pathogenic Fungi. Al-Azhar Journal of Microbiology, 58, 51-60.

[25] Rothrock, C.S. and Gottlieb, D. (1984) Role of Antibiosis in Antagonism of Streptomyces hygroscopicus var. Geldans to Rhizoctonia solani in Soil. Canadian Journal of Microbiology, 30, 1440-1447. http://dx.doi.org/10.1139/m84-230

[26] Compant, S., Duffy, B., Nowak, J., Clement, C. and Barka, E.A. (2005) Use of Plant Growth-Promoting Bacteria for Biocontrol of Plant Diseases: Principles, Mechanisms of Action, and Future Prospects. Applied and Environmental Microbiology, 71, 4951-4959. http://dx.doi.org/10.1128/AEM.71.9.4951-4959.2005

[27] Doolotkeldieva, T. (2010) Novel Antifungal and Bio Stimulator Microbial Products for Sustainable Crop Production in Kyrgyzstan. Materials of 3rd International Conference on the Organic Sector Development in Central Eastern European and Central Asian Countries, Astana, 17-20 September, 132-135.

[28] Doolotkeldieva, T. (2012) Chapter 14. Biological Control Agents for Crop Protection and Sustainability of Agro-Ecosystems in Kyrgyzstan. In: Pillarisetti, J.R., Lawrey, R. and Ahmad, A., Eds., Multifunctional Agriculture, Ecology and Food Security: International Perspectives, Nova Science Publishers, Hauppauge, 197-208.

[29] SAS Institute (1988) SAS/STAT User’s Guide. Release 6.03, 6th Editions, SAS Institute Inc., Cary, 1028.

[30] Nichiporovich, A.A. (1975) The Theory of Photosynthetic Productivity of Plants and Rational Directions of Breeding for Increasing the Productivity/Physiological and Genetic Basis of Increasing the Productivity of Crops: Collection of Scientific Papers. Kolos, Moscow, 5-14.

[31] Kruzhilin, A.S. (1975) Physiology of Development and Productivity of Plants: Collection of Scientific Papers. Kolos, Moscow, 53-63.

[32] Vasilenko, I.I. (1978) Features Photosynthetic Productivity and Yield for Mation of Winter Wheat Varieties of Intensive Type. Journal of Agricultural Science, 7, 18-26. 
[33] Nannipieri, P., Ascher, J., Ceccherini, M.T., Landi, L., Pietramellara, G. and Renella, G. (2003) Microbial Diversity and Soil Functions. European Journal of Soil Science, 54, 655-670. http://dx.doi.org/10.1046/j.1351-0754.2003.0556.x

[34] Bastida, F., Zsolnay, A., Hernández, T. and García, C. (2008) Past, Present and Future of Soil Quality Indices: A Biological Perspective. Geoderma, 147, 159-171. http://dx.doi.org/10.1016/j.geoderma.2008.08.007

[35] Garland, J.L. and Mills, A.L. (1991) Classification and Characterization of Heterotrophic Microbial Communities on the Basis of Patterns of Community-Level Sole-Carbon-Source Utilization. Applied and Environmental Microbiology, 57, 2351-2359.

[36] Degens, B.P. and Harris, J.A. (1997) Development of a physiological approach to measuring the catabolic diversity of soil microbial communities. Soil Biology \& Biochemistry, 29, 1309-1320.

[37] Campbell, C.D., Chapman, S.J., Cameron, C.M., Davidson, M.S. and Potts, J.M. (2003) A Rapid Microtiter Plate Method to Measure Carbon Dioxide Evolved from Carbon Substrate Amendments so as to Determine the Physiological Profiles of Soil Microbial Communities by Using Whole Soil. Applied and Environmental Microbiology, 69, 35933599. http://dx.doi.org/10.1128/AEM.69.6.3593-3599.2003

[38] Degens, B.P., Schipper, L.A., Sparling, G.P. and Duncan, L.C. (2001) Is the Microbial Community in a Soil with Reduced Catabolic Diversity Less Resistant to Stress or Disturbance? Soil Biology and Biochemistry, 33, 1143-1153. http://dx.doi.org/10.1016/S0038-0717(01)00018-9 